\title{
Retailing, Clothing and Textiles Production in Australia
}

Sally Weller*

*Senior Research Fellow at the Centre for Strategic Economic Studies, Victoria University, Melbourne

Working Paper No. 29

Centre for Strategic Economic Studies

Victoria University

October 2007

PO Box 14428

Melbourne VIC 8001 Australia

Telephone +61399191340

Fax +6139919 1350

Website: http://www.cfses.com

Email: csesinfo@vu.edu.au

Contact: sally.weller@vu.edu.au 


\title{
Retailing, Clothing and Textiles Production in Australia
}

\author{
Sally Weller $^{1}$
}

Keywords: Australia, clothing, textiles, retailing, trade liberalisation

\section{Introduction}

Although the Australian textiles and clothing manufacturing industries have been contracting steadily since the early 1970s, the range of activities involved in bringing clothing and related products to the market remain a major component of the national economy and an important source of employment, especially in urban areas. This paper provides an overview of the actors engaged in bringing clothing and clothing-related textiles to Australia's consumer markets. It considers the consumer market, garment retailing, importing, wholesaling, garment production and garment-related textiles production as well as the various intermediaries who link these functions together and ensure that the garments reaching consumer markets accord with consumer tastes.

The organisational configuration of the clothing and related industries in Australia differ from those in Europe and the United States for four principle reasons. First, the unique configuration of the Australian space-economy constitutes a major barrier to firm growth. The vast distances between urban centres and the sparse population densities within cities make it difficult for firms to develop national markets. Consequently, in most industries one or two large firms specialising in high volume products dominate at the national scale, whilst large numbers of smaller firms operate in local, city-wide or State territories. This geography encourages firms to serve specialised niche markets and to create multiple quasi-monopolistic market spaces. In the clothing and related industries, these circumstances are intensified by Australia's informal lifestyle and moderate climate, which depresses per-head expenditures on clothing and encourages national firms to concentrate their activities in sports wear and casual wear markets.

Second, Australia's southern hemisphere location means that its seasonal rhythms are the reverse of those in Europe, an accident of geography that effectively puts Australia six months behind the leading edge of 'global' fashion trends (Weller 2007). As a result, the rapid stylistic innovation cycles characteristic of European 'fast fashion' are less pronounced in the Australian context. At the same time, Australia's location close to Asia has enabled firms to cost-effectively access China's massive production capacity. However, since international 'buying power' is a function of sales volume, the internationalisation of the industry has tended to empower large national firms.

Third, Australia's policy attitude to the clothing and textiles industries is unique among Western economies. Australia liberalised its trade policies and opened its markets to imported clothing in the late 1980s and early 1990s, well ahead of the trade liberalisation schedules of

\footnotetext{
1 Sally Weller is Senior Research Fellow at the Centre for Strategic Economic Studies at Victoria University in Melbourne Australia. She has extensively researched the restructuring of firms and labour in the Australian textiles and clothing industries.
} 
the World Trade Organisation's Agreement on Textiles and Clothing (which have guided the pace of liberalisation elsewhere). ${ }^{2}$ Moreover, and in contrast to the United States and Europe, Australian policies have not enabled firms to develop effective and sustainable off-shore assembly structures in nearby countries.

As a result of these conditions, a high and increasing proportion of garments sold in the Australian market now originate in China. However, the structures through which these imports enter Australia - and therefore the distribution of profit along garment supply chains continues to change with factor prices, trade policy reform and the shifting geography of expertise in Australia, Hong Kong and China.

To explore these trends, the remainder of the paper first provides an overview of the sector's development over the last twenty years, emphasising trade and industry policy reforms, the internationalisation of the supply structures and the consequent rationalisation of domestic production. It then describes in turn the consumer market and garment retailing; the internationally integrated reconfiguration of clothing importing and wholesaling; and finally domestic clothing and textile manufacturing. The discussion highlights how the sector's reconfiguration in the last twenty years has transformed the relationships between these subsectors, often blurring the divisions between them as firms' activities extend to span multiple stages of the commodity production sequence. The paper concludes with some observations about the likely future trajectory of Australia's clothing and related industries.

\section{Australia's Textiles and Clothing Industries}

Throughout the early years of Australia's development, when (Keynesian) national policies promoted nation-building, employment creation and industrialisation, successive governments set trade policies to protect local clothing and textiles (C\&T) manufacturing industries from competing imports. As intended, the C\&T industries became a major source of low-skilled employment, especially for women and migrants. Industrial protection created a 'branch plant' economy in which overseas firms wishing to access the domestic market were impelled to establish production facilities in Australia, literally 'inside' the tariff wall. But parent firms tended not to locate specialised production or research and development functions in Australia. High value commodities were imported, generally from the United Kingdom.

As the world-wide economic crises of the 1970s made it increasingly difficult for the national government to maintain demand management policy settings, market-oriented economic theories gained ascendancy (Pusey 1991). In the context of increasing concern that Australia was falling behind in the race for economic growth, industry protection came to be viewed not only as inefficient and impractical, but as impeding Australia's prosperity. The policy community became convinced that Australia should internationalise its economy and integrate its industries into global trade flows. There was, however, considerable disagreement about how this reorientation should be achieved. Some argued that policies should promote industries in which Australia already held a 'natural' comparative advantage (for example, in agricultural production), while others sought to support emerging industries in which Australia could develop a competitive advantage (for example, knowledge-intensive industries and the production of elaborately transformed manufactures). ${ }^{3}$ Both visions saw the clothing and

\footnotetext{
2 Australia had not been a party to the later versions of the GATT Multi-fibre Arrangement (MFA), primarily because it lacked the market power to negotiate bilateral trade restrictions (Snape et al. 1998).

3 The theory of comparative advantage (Ricardo, 1981 [1817] posits that aggregate welfare is maximised when all nations specialise in the industries in which they enjoy a factor price advantage (that is, an advantage in the cost
} 
related manufacturing industries as low skill and low productivity sectors that were better suited to the economies of developing nations with 'abundant' less skilled labour (Anderson and Garnaut 1987).

After the election of the Hawke (Labor) government in 1983, Australia began implementing a new strategic vision in which revitalised, high technology industries would lead Australia's repositioning in the global economy. Four compelling arguments recommended dismantling the trade barriers that protected Australian clothing and textiles manufacturers from overseas competition. First, given Australia's relatively high wages, clothing and textiles producers were inefficient by world standards. Government support was therefore inhibiting the flow of capital to more efficient activities in which Australia could potentially develop 'internationally competitive' export industries. In addition, it was apparent that the structure of Australia's quota-based system of protection had distorted local industry structures in ways that encouraged anti-competitive practices. Because quotas had been allocated to importing firms rather than to exporting nations, they had empowered large firms and encouraged hostile take-over activity. Second, allowing overseas-made commodities into the local market would increase welfare by increasing the choices available to Australian consumers. Third, opening the Australian market to imported garments would reduce clothing prices and enable households to redirect their expenditures to more technologically advanced products and services. Again, this would promote the economy's reorientation to more advanced industries. Fourth, and perhaps most importantly, demonstrating to Australia's trading partners that Australia was serious about its commitment to trade barrier liberalisation would help unlock market access for Australia's efficiently-produced agricultural commodities and minerals exports.

In 1988, after a major inquiry into the future of clothing and textiles sector (IAC 1986), the government embarked on a structural adjustment program comprising: (1) liberalisation of the tariff, quota and bounty provisions that had protected the C\&T sector from competition; (2) the introduction of incentives for the industries to restructure for 'internationally competitive' operation; and (3) a labour adjustment scheme to assist workers who would be displaced in the ensuing rationalisation process (Button 1986). These reforms were vigorously resisted by textiles and clothing firms and workers, but were supported by retailers who were keen to secure greater access to imported garments.

The statutory body set up to promote the reform process, the Textiles Clothing and Footwear Development Authority (TCFDA), directed its energies to modernising the textiles sector, which, given its capital-intensive nature and the obvious opportunities for 'downstream' processing of Australia's wool and cotton production, was adjudged to be potentially competitive in an open economy. The TCFDA directed less attention to the clothing production industry, which was deemed unlikely to prosper without trade protection. ${ }^{4}$ In March 1991, in response to the perception that C\&T firms were not restructuring quickly enough, the government unexpectedly accelerated the pace of trade barrier liberalisation (Hawke et al. 1991).

of labour or materials or land). The alternative view, associated with Porter (1990), is less deterministic, arguing that advantage can be created by working 'smarter' and targeting interventionist policies to strategic advantage.

4 Since these policies assumed that firms operated independently in competitive markets, they did not consider how interventions would impact on the relationships between textiles production, clothing manufacture and retailing; how they would change the power relations between small and large firms in complexly inter-dependent supply structures; or how reduced duty rates would impact on firm profitability in a finite market. These matters are discussed in detail in Webber and Weller (2001). 
As these policy settings came into effect in the recession years of 1991-1993, large numbers of clothing and textiles firms closed down or significantly restructured their operations. Retailers and wholesalers increased their direct importing, buying at prices well below local production costs. Some clothing manufacturing firms went out of business as their orders evaporated or as their suppliers of essential inputs closed down. Others - predominantly larger firms with knowledge of the policy direction and its implications - closed local factories and shifted the labour-intensive aspects of their production overseas. They retained 'core' planning, design, research and merchandising functions in Australia but either opened subsidiaries in China or Fiji or shifted to a (vertically disintegrated) subcontracting model using cut-make-trim (CMT) contractors. Many local textiles producers, including some of the most technologically advanced firms, failed as their clothing industry customers exited local production.

As the 'old' industry restructured, a new generation of firms - often established by displaced former production managers - entered the market to create new industry structures. These importers, merchandisers, quality control specialists, logistics consultants and the like became intermediaries in the transformation of the relationship between retailing and production. As the recession ended after 1993, they were joined by new locally-based CMT production subcontractors that organised their production around a home-based workforce. In the second half of the 1990s, the intense competition generated by rapid trade liberalisation tested the efficiency of competing models of industrial organisation.

In 1992 and 1994 the Government introduced new policies intended to encourage internationalisation, to support technologically advanced textiles production and to sustain local clothing brands. These initiatives encouraged the 'offshore assembly' of garments and provided incentives for export market development (Commonwealth of Australia, 1994). However, by 1997, when the Government again reviewed the textiles and clothing reform process (IC 1997), these industry incentives had been outlawed by the World Trade Organisation. They were replaced in 2000 by a WTO-admissible incentive scheme promoting innovation and structural reform to assist firms further 'consolidate' their activities and 'adjust' their labour requirements. The Government also resolved in 1997 to slow the rate of industrial change by pausing tariff reductions in the years 2000 to 2005.

In January 2005 the liberalisation process recommenced. Import duty rates on clothing fell to $17.5 \%$. They will fall incrementally, to $10 \%$ in 2010 and then to the same rate as other manufactured goods - 5\% - in 2015. However, these duty rates do not apply universally: imports from developing countries attract a 5\% concession; imports originating in New Zealand (with which Australia shares a common market) are free of duties; and production inputs are duty-free when there is no competing local production. As tariff barriers fall, garment related importing and exporting is governed increasingly by fluctuations in the Australian dollar's exchange rate. The main beneficiaries of higher exchange rates are clothing importers that can buy more with each Australia dollar, whilst the main losers are Australia's handful of garment exporters (La Frenz 2007). Counter-intuitively, however, the strong Australian dollar in 20062007 has appeared to have promoted local production by reducing the costs of (imported) fabrics.

In 2007, the local garment and garment-related textiles production industries are still declining, with production falling by $8 \%$ between 2001-02 and 2004-05. Nonetheless, the sector still accounted for AUD $\$ 5$ billion of GDP in 2004-05, contributed $\$ 1532$ million of added value to 
the economy, and represented about $1.6 \%$ of total manufacturing industry value added. ${ }^{5}$ Employment numbers also continue to decline: by June 2005, the sectors employed 29,748 people, a fall of almost 25\% since June 2002 (ABS 2006a). According to Australian Bureau of Statistics' time series data for the broader classification 'Textiles Clothing Footwear and Leather Industries' (ABS 2007a), full-time employment fell by $60 \%$ in the twenty years 1985 to 2005 , from 104,800 to 42,800 workers. The jobs that were eliminated in the restructuring process were mainly less skilled jobs, especially clothing machinist jobs (which in Australia are gender-typed as women's work). Accordingly, the job losses have affected women's jobs (43,400 jobs, or $64 \%$ of the 1985 workforce) more than men's jobs $(19,400$ jobs, or $53 \%$ of the 1985 workforce). ${ }^{6}$ In aggregate, some of the decline in manufacturing employment has been offset by increased employment in clothing importing, wholesaling, retailing, and various associated services. The next sections describe in turn how these overall changes have altered the clothing and fashion industries.

\section{Clothing Markets}

It is not possible to understand the structure of Australia's clothing industry without first understanding the characteristics of its clothing markets. Like other Western markets, the Australian market is highly segmented or fragmented: not only into income-related strata, but also into segments defined by combinations of gender, age, body type (size) and aesthetic preferences. These break the market up into multiple small national markets defined by lifestyle preferences.

Australia's casual lifestyle and moderate climate leads Australians to spend less on clothing than people in otherwise comparable Western economies. In 2005-06, retail turnover in 'Clothing Retail' stores was estimated at AUD $\$ 10.1$ billion, suggesting that after the addition of clothing sales in Department stores, about AUD $\$ 14$ billion is spent on clothing each year (ABS 2006b). To put these figures in an international perspective, Australia's population is about one third the population of the United Kingdom (20 million compared to 60 million), but its clothing market is only one seventh the size (roughly, AUD $\$ 14$ billion compared to AUD $\$ 100$ billion). Moreover, the Australian market is spread across a land area about 30 times larger than the United Kingdom. By international standards, then, the Australian market is thin indeed. This context militates against the development of strong national markets in any but the most popular lifestyle segments.

As an outcome of Australia's geography, Australians spend relatively high proportions of their household incomes on housing, transport and communications equipment. Household expenditure data (ABS 2006b) reveals that the three lowest income quintiles spend respectively AUD $\$ 12.75, \$ 19.50$ and $\$ 30.68$ per week on clothing, whilst the upper two quintiles spend AUD $\$ 46.40$ and $\$ 67.07$ per week. Only in the highest income quintile does weekly household expenditure on clothing exceed expenditures on alcohol and cigarettes.

\footnotetext{
5 These figures are based on the author's calculations from ABS Manufacturing Industry data (ABS 2006a) after excluding the contributions of industrial textiles and early stage wool processing.

${ }^{6}$ The accuracy of official statistics is open to question given uncertainty about the extent to which the home-based clothing 'outworker' workforce (numbering perhaps 60,000 intermittently employed or 20,000 equivalent full-time workers) is counted in official data. The most recent Census data (2007c) puts Clothing, Textile, Footwear and Leather industry employment at 64,595 , considerably higher than Labour Force estimates. The difference may reflect different sampling methods, intermittent workers, clothing workers in the cash economy, or workers who self-identify as part of the textiles and clothing sector but would be classified in the Australian and New Zealand Standard Industrial Classification (ANZSIC) - which guides the Labour Force data structure - as working in the personal services or business services sectors.
} 
Clothing's share of household expenditure has fallen over the last ten years, partly as a result of real price reductions associated with trade liberalisation, but also because other products (such as mobile phones and i-pods) have captured consumer interest (ABS 2007b).

In addition to changes in trade and industry policy, other regulatory changes have contributed to the restructuring of retail markets. Most Australian states deregulated trading hours during the 1990s, thereafter allowing stores to remain open for long hours, including Saturdays and Sundays. Subsequently, a high proportion of the retail sector workforce has been employed on a part-time and casual basis as retailers tailor their staffing to the daily, weekly and annual rhythms of demand. For many people, shopping - or perhaps window-shopping - has become an important recreational pastime. The introduction of the Goods and Services Tax in 2000 (and the simultaneous abolition of sale tax) had complex impacts on relative prices, but on balance was favourable to clothing sales.

The increasing workforce participation of Australian women, the ready availability of credit (cards), new mass communications technologies and the changing strategies of retail firms have altered local buying patterns. The media, now extended to include the internet, cable TV and email, has been influential in altering the character of consumer preferences, most recently by encouraging fashion-savvy consumers to eclectically select items from across a range of price and brand categories (Tungate 2005). The fashion event industry now also plays a powerful role in shaping consumer tastes in the fashion-oriented parts of the market. Importantly, as these activities insert a new tier of specialised intermediaries - stylists, event staging specialists, fashion journalists and a range of marketing roles - between clothing retailers and consumers, they tend to blur the boundaries between the clothing industries and other fashion-related consumer products sectors. Finally, as firms across the sector have focused on their 'core' activities, a new business services sector has developed to assist retailers, wholesalers and manufacturers with market and consumer research services, business planning, benchmarking, design services, computing, pressing services, logistics and a range of advanced retail and stock control technologies. Although many of these associated businesses work exclusively for garment industry clients, they appear in aggregate data in business service industry categories. In other words, if these new specialised businesses were considered a part of the clothing sector, the local industry's contraction would not be as severe as the official data suggests.

\section{Clothing Retailers}

In June 2001, Australia's 10,673 clothing retailing establishments were distributed across the nation in rough proportion to population densities - that is, concentrated in the key cities of Sydney, Melbourne, Brisbane and Perth (ABS 2006c). The structure of the Australia garment retail sector reflects its historical development. Under industry protection before 1990, clothing retail markets were dominated by the firms that controlled access to import quotas and therefore the supply of imported garments. When quotas were abolished in 1993, retailers quickly re-organised their supply chains, jettisoning relationships with local manufacturers and shifting to direct or sub-contracted importing. Consistent with overseas trends in retail management, retailers also increased their investments in brand identity and customer loyalty. Often they became more involved in micro-managing subcontracted production to ensure that garments reflected (or, more exactly, became a material form of) retail brand identities. Changes to the scope of retail operations were facilitated by technological advances that have enabled retailers to accurately track sales, more actively manage their supply and distribution chains, reduce inventories and limit (end-of-season) stock mark-downs (Greig 1990). These 
innovations have also enabled multi-store firms to consolidate and centralise their warehousing functions.

Overall, since the early 1990s many firms that were formerly 'pure' retailers have either incorporated their wholesaling functions or formed close alliances with quasi-independent wholesalers. Although subcontracting has been the dominant sourcing model, albeit with varying degrees of retailer control, some smaller volume specialised retailers have established their own vertically-integrated production facilities in the 'Benetton' model. ${ }^{7}$ These trends have in part produced and in part reflected the shifting competitiveness of different forms of retailing. In Australia, clothing retailing takes four main forms: Department stores, specialty retail chains, boutiques and other retailers. Since liberalisation, the configuration and market shares of different forms of clothing retailing have altered with the changing competitiveness of different garment sourcing strategies. In 1998/99, the last year for which detailed data is available, dedicated clothing stores (that is, specialty chains and boutiques) held a $40 \%$ share and Department stores held a 34\% share of Australia's clothing market. The remainder comprises of sales in supermarkets, lifestyle stores and other outlets. It is likely that the Department store share has increased in recent times.

\section{Department Stores}

In Department stores, clothing represents a significant proportion of total sales. Australia's highly concentrated Department store sector is dominated by two national firms operating in mainstream markets and two national firms competing in the discount sector.

At the high end of the market David Jones and Myer stores have competed for supremacy in fashion-oriented clothing markets. Both have sought to attract local fashion designers to exclusive 'store within a store' concessions, but David Jones's pioneering decision to favour 'edgy' Australian and New Zealand designers has - at the time of writing - positioned it as the clear leader. In addition to stocking elite designer garments, both stores offer a range of less expensive clothes at multiple price points, including designer 'diffusion' labels and each store's 'own-brand' versions. The most recent innovation is the introduction of cheaper 'diffusion' versions of Australian designs. ${ }^{8}$ It appears that in the Department store environment, local designers have been able to compete successfully against high-profile imported designer brands. In addition, the competition between high-end Department stores has generated positive spin-offs across the industry through increased interest in fashion. It also appears to have improved the position of Department stores relative to specialty retailers, in terms of both sales and fashion status.

The discount department store sector is also concentrated. It is dominated by two multi-store brands, Target and Kmart. Both operate within the Coles group of companies. ${ }^{9}$ Throughout the 1990s, Target Stores operated in what is known locally as the 'Marks \& Spencer' organisational model. It stocked quality, reasonably priced Target-brand garments made by preferred suppliers in accordance with Target's own standards and specifications. Kmart's 'Now' brand clothing, on the other hand, targets a more budget oriented market and its stock is predominantly imported from China. In both Target and Kmart stores, significant

\footnotetext{
${ }^{7}$ However, store franchising, another feature of the Benetton model, is rare in Australia.

${ }^{8}$ Given low sales volumes, there is some doubt whether or not Australian designers that introduce diffusion labels will be able to maintain their elite status (Safe 2007).

${ }^{9}$ At the time of writing, Coles was the subject of a take-over bid by private equity interests. It appears likely that the group will be broken after its sale.
} 
proportions of stock are Australian icon brands, sourced from local wholesale firms but manufactured in China. The imported proportion of discount store stock has increased recently with firm-level policy changes and with the escalating value of the Australian dollar.

Target has recently embarked on a 'fast fashion' strategy, engaging well-known fashion designers (Stella McCartney then Josh Goot) to produce one-off budget-priced ranges. This 'massification' of design is a strategy borrowed from European retailers. Its appeal is the momentary illusion of scarcity created by combining limited availability with concentrated marketing. This represents a significant shift in the structure of the fashion system in Australia and may pose a threat to the market position of mid-range (that is, specialty) fashion firms (Meagher 2007).

\section{Clothing Chain Stores}

The speciality clothing retail sector includes national chain stores, smaller regional chains and highly specialised niche chains. Six national clothing chain retail groups - the Just Group, Retail Holdings, Specialty Fashion Group, Colorado Group, Country Road and Noni B - are included among Australia's Top 20 retailers and together account for a large proportion of the total specialty store sales. These firms typically control a stable of multi-store retailer brands, each targeting a different segment of the market - a strategy that moderates the risks associated with fashion unpredictability. National brands are represented in most of the nation's shopping malls and main shopping precincts and have in the range of 180-300 stores each. As in other parts of the world, the garments, store designs and staff profiles within each brand aim to present a coherent image targeted to a specific lifestyle demographic. By emphasising product differentiation and customer loyalty within niche markets, brand strategies aim to build quasimonopolistic control over a (small) market. Most clothing chain stores have expanded their product ranges to now include complementary footwear and accessories.

Growth in the specialty sector is driven by new store openings and acquisitions. New stores generally open in parallel to new shopping centre developments. In fact, it could be argued that the specialty clothing sector relies on the property development sector for knowledge of demographic trends and shifting regional fortunes. However, firms use acquisitions - either of competitors or of complementary brands - to increase their market share and profitability. Over the last ten years, this has resulted in a dramatic increase in ownership concentration.

- The Just Group is now one of Australia's largest specialty retailers with about $5.8 \%$ share of the local market. It originally specialised in denim street-wear, but now holds multiple brands: Just Jeans (285 stores in 2006), Jay Jays (227 stores), Portmans (116 stores), Jacqui-E (97 stores), Peter Alexander (9 stores) and Dotti (48 stores).

- Retail Holdings Pty Ltd was formed after Sussan Corporation purchased the ailing younger fashion chain Sportsgirl in 1999. It includes women's fashion brands Sussan, Sportsgirl and Suzanne Grae stores and is the only one of the sector's large firms to have remained in private ownership.

- Specialty Fashion Group was created after budget Miller's Fashion Club purchased the Katies chain in 2001. It has also acquired Crossroads (150 stores), Autograph (100 stores) and Big City Chic (25 stores). It purchased its largest supplier, Look Sharp Concepts Pty Ltd in January 2002. 
- In addition to its independent brand stores, up-market Country Road operates concessions in major department stores. In 2004-05, it also supplied wholesale garments to Myer Department stores.

- The Noni B group, comprising the Noni B, Liz Jordan and La Voca brands, has over 200 stores, many of them in regional areas.

- ARH Investments (Australia) Pty Ltd purchased the Colorado Group (105 stores) in September 2006. The Group acquired the Palmer Corporation in 2001 to gain control of the upmarket Jag label (35 stores).

- Pretty Girl Fashion Group is owned by Consolidated Press Holdings. It operates 300 Rockmans Stores, 15 Hiltons stores and 22 BeMe boutiques. It purchased Table Eight corporate wear in 2004.

- Other important groups include: the up-market Witchery chain which has more than 70 stores in Australia and operates concessions within David Jones Department stores; Jeans West, which has grown to 150 stores; Cue fashion stores; the teen label Supré; Lowes-Manhattan, which operates 110 Lowes menswear stores; and the Esprit clothing group. M. Webster Holdings Pty Ltd, the holding company for the Jigsaw and David Laurence brands, is developing a high fashion niche after purchasing the Marcs and Morrissey businesses in 2006.

The specialty retail sector is predominantly locally owned, but many firms have listed on the stock exchange in the last 10 years. For example, Noni B was listed in 2000 and the Just Group in 2004. Listing helps firms raise capital, but the discipline of the share price may discourage the risk-taking characteristic of fashion leaders. Private capital is increasingly influential: private equity firm Gresham purchased Witchery and a private group (including Texas Pacific and Myer family interests) purchased Myer Stores in 2006. Colorado's owner ARH Investments is owned by Hong Kong's Affinity Equity Partners and in 2007 was moving to return the firm to private control. In 2007, Specialty Fashion Group and Just Group were also offering investors share buy-back schemes. Influential private investors (such as former Myer director Solomon Lew) play important strategic roles in the configuration of capital across the Australian fashion retail sub-sector.

In the late 1990s European designer brands aggressively moved into the Australian market, but few prospered beyond the tourist precincts of capital cities (primarily due to their uncompetitive prices). However, some overseas brands have consolidated their position in the market through exclusive licensing arrangements. The publicly listed Oroton Group Limited, for example, holds the licence for the Oroton and Polo Ralph Lauren brands in Australia. ${ }^{10}$ In addition to operating its own stores, Oroton supplies Myer and David Jones stores. More often, overseas interests access the Australian market via the acquisition of local brands. Country Road, for example, is owned by the South African Woolworths group and Jeans West by Hong Kong's Glorious Sun Enterprises. Overseas brands (for example Jigsaw, Laura Ashley, FCUK and Giordano) are represented only in major cities. The largest global players (Gap and Zara, for example), have not entered the Australian market.

During the 1990s, when the federal government was promoting export market development and offering assistance to exporters, a number of larger Australian fashion chains attempted to enter the US and other export markets. These ventures generally failed. However, Australian surf-wear firms - principally Billabong and Rip Curl - have become influential transnational companies. More than half of Billabong's revenue now derives from overseas

\footnotetext{
10 Australia has permitted 'parallel importing' since 1998, but garments imported by that means are mainly sold in designer discount stores.
} 
sales. In addition, numerous Australian fashion designers market their products through specialist retailers (such as Antipodium in London), major Department stores in high income countries and on-line. Since the establishment of a common market between Australia and New Zealand, Australia's more upmarket chains - Country Road, Witchery and Sportsgirl have increased their presence in New Zealand, while a handful of New Zealand retailers, such as Zambesi, have expanded into Australia.

\section{Small Businesses and Boutiques}

Australia has a large number of small businesses involved in clothing retail. Boutique clothing stores are generally independent businesses, with one or two shops located in adjacent suburbs. They typically employ less that six people. High fashion boutiques frequently stock garments brought to them by local designers, and sometimes retail on a commission or on a sale-or-return basis. In major cities, specialist 'directional' boutique retailers, such as Alice Euphemia in Melbourne, act as intermediaries linking emerging young designers with mainstream markets.

\section{Other Clothing Retail Outlets}

A considerable proportion of clothing in Australia is sold in lifestyle stores that combine clothing with adventure or sporting product sales. These stores are popular with less fashion-aware consumers and include retailers such as Rebel Sports, Ray's Outdoors, Kathmandu and Mountain Designs. Shopping for bargains is a popular pastime for some Australians. Bargain clothing can be found in street markets, factory outlets and discount or liquidation stores. Property developer Austexx has created numerous DFO (Designer Fashion Outlet) discount fashion complexes in recent years. These stores attract 'factory shop tour' groups from regional areas. In 2007, internet-based clothing retailing had not yet captured the imagination of Australian consumers despite high rates of internet use.

\section{Sourcing and Importing}

All imports to the Australian market arrive as the result of purposeful sourcing activities by firms in different parts of the clothing production system. Retailers, agents and wholesalers draw on similar sourcing strategies and most use a combination of strategies, sourcing garments locally and from overseas depending on the fabrics, labour content and fashion orientation of particular styles in the context of cost, quality and time comparisons. Strategies - and therefore the ratio of locally made to imported products in the market - may shift from season to season or stock turn to stock turn, depending on the fashion mood, the exchange rate and the availability of manufacturing capacity.

Before trade barrier liberalisation, garment importing had been governed and constrained by the quota system. But after liberalisation, larger manufacturers 'hollowed out' their operations, retaining management, design and logistics functions in Australia whilst shifting their manufacturing activities to low wage countries, principally to China. In effect, they became importers. Australia's largest clothing manufacturer Pacific Dunlop, for example, initially closed down local production (with the loss of some 10,000 jobs) and opened its own factories in China. But these factories were later sold, and Pacific Dunlop became a sourcing wholesaler, Pacific Brands. 
A second sourcing strategy for former manufacturing firms has been to opt for managed 'cut-make-trim' production in Fiji, where local economic development and trade incentives have facilitated the creation of a competitive production structure. This form of offshore production created a new group of intermediaries specialised in the technicalities of trade and customs rules. For a variety of reasons, however, these schemes have not produced the robust transnational assembly structures achieved in the United States and Europe (Weller 2000). ${ }^{11}$ The strategy became less attractive when policy incentives were discontinued in 2000 , and the production model declined rapidly after Fiji's 2000 political coup d'etat (Weller 2006). Nonetheless, Fiji production suited the needs of Australian clothing firms with a genuine design edge, especially medium fashion surf-wear firms.

Larger retailers tend to work directly with agents in Hong Kong or China, often reducing their decision set by using the same agent as an overseas brand targeted to a similar demographic profile. Firms can choose whether to have garments made to their own specifications, to have generic designs modified to better accord with their brand image or with local aesthetic preferences, or to simply buy a design from a catalogue. Increasingly, brandowners (which include retailers and former manufacturers) buy fully designed garments from OEM (Original Equipment Manufacture) firms, following the European trend to 'fast fashion' (the 'Zara' model), although Australia's off-season location blunts the fashion edge of this strategy. ${ }^{12}$ Basic staple garments (a black shirt, for example), can be purchased in 'spot' markets in Hong Kong or China.

After liberalisation, less resource-rich manufacturing firms adopted a 'vertically disintegrated' subcontracting model, either forming direct relationships with factories in China or securing the services of agents in Hong Kong to arrange manufacture in China on their behalf. However, these firms often under-estimated the hidden costs of overseas production or misjudged the challenges of quality control. In addition, their small orders put them at a bargaining disadvantage in Hong Kong's global markets. Some firms returned to local manufacturing, while others transformed again to become importers of overseas designed garments.

The sourcing strategies of boutiques and other small retailers vary with firm size, fashion orientation and brand identity. Small retailers in regional Australia often purchase stock through buying groups that operate in a similar way to retail chains. Smaller retailers also purchase independent brand garments from agents who act on behalf of manufacturers (in Australia or China), or from wholesalers that purchase stock overseas and on-sell it to local retailers. However, retailers operating in high fashion markets will source small volumes directly from overseas designers.

As a result of these reconfigurations, the import share of domestic demand for 'Clothing and Knitting Mill' products has increased steadily from $18.5 \%$ on $1990-91$ to $51.8 \%$ in 2000-01 (TFIA 2006). The import share varies from product to product, but had reached $60 \%$ or over in most outerwear sub-segments by 2001-02 (ABS 2007d). The largest percentage increases since 2000 have been in the women's and girl's wear segment, a part of the industry that was previously assumed to enjoy a 'natural' protection derived from local fashion preferences. The annualized rate of growth of imported women's and girl's clothing was $10 \%$ in

\footnotetext{
11 The United States' Maquiladora production system is described in Bair and Gerrefi (1998); for the European Outward Processing Trade see Scheffer (1994).

12 After embracing 'fast fashion', Just Jeans has reduced its product cycle to 12-14 weeks, enabling 4.7 stock turns in 2006 (Just Group 2006).
} 
2000-01 to 2005-06, compared to 3.3\% in men's and boy's clothing (TFIA 2006). These trends reflect the different rates at which the production of different commodities has moved offshore. For men's and boy's clothing, the rate of import penetration has slowed compared to the mid 1990s. These changes also reflect China's expanding capacity, which now accounts for over $70 \%$ of all garment imports (TFIA 2006), as well as improved transnational transport and logistics services and the growth in fashion imports from New Zealand.

\section{Wholesaling}

Wholesalers have facilitated much of the growth in Australia's clothing imports. Since trade barriers were liberalised the clothing wholesale sector has grown significantly. Between 1986 and 1996, the clothing wholesaling workforce grew by $31.1 \%$, from 12,801 to 16,785 (Webber and Weller 2001). In recent years, new entrants to this sector have included firms established by recently arrived migrants with links into China (especially people emigrating from Hong Kong after 1997). These intermediaries have a dual role: they link retailers to manufacturers and at the same time manage the relationship between importing and local production.

Since Australian retail markets are fragmented and include large numbers of small firms, Australia's specialised sourcing and wholesaling sector plays a powerful role in garment supply chains. The upshot is that the Australian clothing supply industry does not always accord with the 'retailer-led' supply chain structure characteristic of globalised firms (see Gereffi 1994). Rather, Australian supply structures are shaped by the uneasy power relationship between major retailers and the brand-owning wholesalers that control large segments of garment import trade. Although the wholesale sector includes large numbers of very small firms, the national scene is dominated by two key players: Pacific Brands and Gazal Corporation.

Before trade liberalisation, Pacific Brands had been Australia's largest clothing manufacturer. In the early 1990s it restructured, closed down most of its clothing production facilities, and recreated itself as a brand manager, wholesaler and distributor, specialising in basic necessities such as underwear and commodity outerwear. It employs approximately 9000 people, making it one of Australia's largest employers. Each year, it manufactures or sources in excess of 160,000 products, and sells over 250 million units. Pacific Brands is a leading supplier to the four main Department store retailers. Its products are sold by independent retailers (44.6\%), discount department stores (28.9\%), department stores (15.2\%), and supermarkets (5.5\%). The remainder is exported, mainly to New Zealand. In 2007, Pacific Brands controlled many of Australia's 'icon' clothing brands. ${ }^{13}$ Throughout its history, Pacific Brands has grown through acquisitions. The King Gee and Stubbies labels were acquired in 2001 after it purchased Sara Lee Apparel. In 2006 it added Peri bed-linen and the DKNY licence, and later that year acquired the Globe street-wear brands (Mossimo, Stuzzy, Mooks, Paul Frank, Freshive, Independent and M-ONE-11). In 2007 it purchased the Australian icon work-wear firm Yakka and its brands Yakka, Hard Yakka, and Can't Tear 'Em.

Much of Pacific Brand's contracted production is carried out in China, where the group has more than 1000 employees (based either in China or Hong Kong). It has recently entered a joint venture with Asian conglomerate Li \& Fung to develop a technologically advanced warehouse complex in Shanghai that will reduce lead times, improve inventory control and

\footnotetext{
13 These include: underwear (Jockey, Rio, Bonds, AntzPantz, Underdaks), socks (Holeproof, Explorer Socks), intimate apparel (Berlei, Hestia, Playtex and LoveKylie), hosiery (Kayser, Kolotex, Razzamatazz, Voodoo), workwear (King Gee, Stubbies, Yakka, Hard Yakka, and Can't Tear 'Em) and sportswear (Dunlop, Everlast, Slazenger and Hang Ten). The underwear, socks and hosiery division accounts for almost $40 \%$ of total sales.
} 
enable stock to be delivered directly to customers without warehousing in Australia. The scale of Pacific Dunlop's operations, and its volume-leveraged price advantage, place it in a formidable position in the Australian market. In recent years it has begun to manage the supply chain for other brands; in 2005, for example, it agreed to supply footwear and bed-linen for the Esprit chain.

The second major player in the wholesale market, Gazal Corporation, also restructured in the early 1990's, shifting from direct production to supply chain management. It specialises in business, corporate and school wear though its brands Van Heusen, Midford, Bisley, Paramount and Bracks. It also has multiple youth wear interests including the Nautica, Maui \& Sons, Mambo, Mambo Goddess and SMP brands. Its intimate apparel business specialises in licensing arrangements with fashion brands (Trent Nathan, Calvin Klein, Lovable, Oroton, Crystelle, Kookai, Playboy, Morrissey, Davenport, Body). In 2005, Gazal acquired Bracks Apparel, the uniforms division of Australian Defence Apparel and Ultimate Factory Outlets. In 2006 it added Coronet Corporate, a corporate uniform business.

Three remaining firms that hold substantial positions in the wholesale market are the Austin Group, Voyager Distributing Company and the Discovery Group. The Austin Group is a publicly listed specialist importer that sells its brands through independent retailers and selected department stores. Its brands span women's wear (Rochford, Purr, Contempo, Playboy, Voodoo Dolls, French Kitty, Ivory, Who's Billy, Itsu) men's wear (Roar, Globalocal, Blueprint, Hope \& Glory, Town \& Country, Crusty Demons) and children's wear (Billiecart, Purr Girls, Roar, SP Girl, Nuggets, Milly, NG Surf, Spud, Jimmy Jams, Precious Pumpkins, Baby Gund). Although the Voyager Distributing Company is primarily a wholesaler it combines importing with factory-based local production.

\section{Local Clothing and Textile Production}

As Australia climbed out of recession in the mid 1990s, the clothing production system generated new firms, new organisational configurations and a new workforce. Despite the pessimistic outlook in 1986, the clothing production sector has continued to supply a significant share of local consumption. Although the income generated in local garment-related production sector fell between 2001-02 and 2004-05, it still exceeded AUD \$ 5 billion dollars per annum in 2004-05 (ABS 2006a). The volume of clothing manufactured in Australia fell from 28.8 to 22.8 thousand items between 2001-2002 and 2004-05, a fall of a little less than 20\% (TFIA 2006). In recent years, profit margins have been modest relative to the manufacturing industry average. These figures suggest that the restructuring process has not yet reached a point of equilibrium.

The clothing production sector is characterised by a large number of very small firms. In fact, one quarter of all employees (including working proprietors) work in firms with fewer than 5 workers. The handful of workplaces with 100 or more employees employs a quarter of the workforce. In the financial years 2001-2002 to 2004-05, firms employing between 10 and 50 people grew in relative terms, increasing their share of employment by $7.1 \%$. Australia's clothing production capacity is concentrated in the southern State of Victoria, where $44 \%$ of the industry's sales and service income and $45 \%$ of its IVA is produced (ABS 2006a). Export activity has declined with the withdrawal of export incentive schemes - in the three years 200102 to 2004-05, exports by textiles, clothing, footwear and leather firms (ANZSIC 22) fell by $43 \%$. In 2004-05, 56.9\% of firms in the TCF\&L industries did not export any of their output. As might be expected, small firms are much less likely to be exporters. 
After the crisis of the early 1990s, the clothing production industry regenerated as a production system based on home-based labour, known in Australia as clothing 'outwork.' It mushroomed in the mid-1990s with the fortuitous intersection of buoyant demand, large numbers of skilled clothing workers who had been displaced when factories closed down, and large amounts of unused equipment (which could be bought cheaply at liquidation auctions). By 1995, the Textiles, Clothing and Footwear Union of Australia confidently asserted that domestic production was based on the outwork model (TCFUA 1995). Since 1995, clothing unions have spearheaded campaigns to improve the regulation of labour standards in the outwork sector. Although outwork is regulated under Australia's Award framework, many firms have flouted the law, underpaying workers, ignoring occupational health and safety rules and avoiding taxation obligations. ${ }^{14}$ Because outworker-based production quickly adjusts to shifts in demand and brings garment production 'closer' to the market, it out-performs imports in fashion-oriented segments of the industry (principally because it enables retailers to buy small volumes on demand, keep inventories low and avoid end-of-season markdowns).

After community concern about the plight of outworkers, activist campaigns in the late 1990s managed to recruit firms into a voluntary Outwork Code of Practice. Subsequently, State governments in New South Wales (2001) and Victoria (2003) have legislated to protect outworkers by tightening responsibilities in the supply chain and introducing laws that make an 'apparent' employer higher in the production hierarchy responsible to unpaid wages. In 2006, both States were in the process of introducing mandatory Codes of Practice.

In 2007, Australia's remaining garment manufacturing sector operates at worldstandard productivity levels as lead firms' sourcing flexibility thrusts local manufacturers into direct competition with products manufactured in low wage countries. Because the fragmented local market is too small to generate economies of scale, this context encourages small firms to maximise efficiency and minimise costs - that is, to take the 'low road' to international competitiveness. The strong Australian dollar since 2005 has reduced the cost of inputs and improved the competitiveness of local sourcing. ${ }^{15}$

Currently, the critical issue for clothing manufacturers is Australia's plans to enter free trade agreements with Malaysia, the United Arab Emirates and, most importantly, with China. Although these agreements are likely to preserve existing tariff reduction schedules, industry concerns centre on non-tariff barriers, rules of origin and intellectual property issues. Local firms opposed recent changes to rules of origin for Australia - New Zealand garment trade, for example, arguing that the shift from a $50 \%$ regional value added to a 'change in tariff classification' (CTC) criterion would enable more trans-shipment of otherwise dutiable commodities via New Zealand (PC 2004).

Different issues shape the fortunes of the high technology textiles production industry. In its early years, Australia's garment-related textiles industry had focused on the downstream processing of Australia's wool production. ${ }^{16}$ Until the late 1970s, garment-related textiles production was supported by a structure of yarn bounties, import quotas and tariffs that

\footnotetext{
14 Since 1987 amendments to the Clothing Trades Award (1982), outworkers have been 'deemed' to be employees. Firms that are signatories to the Award are expected to employ outworkers under conditions equivalent to those of factory-based workers.

15 In all likelihood, competitiveness has also been increased by wage cost savings since labour market deregulation has depressed clothing workers' wages (see ACTU 2006).

${ }_{16}$ Garment-related textiles production accounts for a diminishing proportion of the Australian textiles production industry (ANZSIC 22). Industrial and household textiles are not considered in this paper.
} 
prevented cheaper overseas-made fabrics entering Australia. The Government's Tariff Board had micro-managed protection levels with a view to maintaining employment, especially for workers in regional areas. As Australia prepared to liberalise its markets, British capital exited the local textiles sector. Local entrepreneur Abe Goldberg purchased multiple plants, but his empire failed in 1989, marking the beginning of a new era for the local textiles industries. Many less efficient garment-related textiles firms exited the industry in the early 1990s as clothing production moved offshore.

Employment in garment-related textiles fell throughout the 1990s. The position of local textiles firms stabilised briefly in the mid 1990s, as government incentives encouraged the use of Australian fabric in offshore processing firms in Fiji and China. Offshore processing stimulated a new generation of textiles finishing firms specialised in importing basic cloth from Asia, dyeing and finishing it in Australia, and then exporting to Fiji for use in garment manufacture. Finished garments were then re-imported to Australia. When the Fiji production system became uncompetitive after 2000, the fortunes of garment-related textiles firms declined, and a number of larger firms that had struggled to compete in the 1990s finally went out of business. In 2007, surviving textiles production firms were opposing a Fijian proposal to further alter the structure of the SPARCETA trade arrangements to enable Fijian clothing manufacturers to source fabrics from a wider range of origin countries. The disappearance of Fiji's preference for Australian fabric would displace much of Australia's remaining textile production (TFIA 2007).

The garment-related textiles production sector continues to decline. Yarn production fell by more than $60 \%$ between 2001 and 2005 (from 58.6 to 21.6 thousand tonnes), as did broad-woven fabric production (from 131.6 thousand tonnes to 46.7 thousand tonnes). Only the high technology knitting mill sector remains competitive under Australia's current industry policy framework. The hosiery sector, which is controlled by Pacific Brands, experienced the smallest decline in recent years, with employment falling only 5.7\% from 1997/8 to 2002/03 (from 2,259 to 2,130). Pacific Brands upgraded its textiles production capacity significantly with the support of Government subsidies and incentives. The fabric it produces is exported for use in the firms' branded clothing.

There are some positive developments in textiles production. An increasing proportion of local garment-related textiles activity is in textile finishing - technologically advanced processes that 'add value' to basic cloth. Innovations include the application of nanotechnologies and the use of polymers and polyurethanes to produce odour resistant and lightsensitive fabrics, fabrics that offer UV protection, fabrics with advanced flexibility and breathability, and synthetic fabrics that mimic the properties of natural fibres. Global garment firms Levi Strauss, Kathmandu and Champion have incorporated Australian nano-technologies into their products. Government-funded research centres have played a leading role in these developments.

\section{Conclusion}

The Australia clothing and textiles industries have been the first among Western economies to face the realities of open trading arrangements and internationalised markets. The effects were devastating for most of the 1985 workforce (Weller and Webber 1999). However, after twenty years of reform, some parts of the industry have established a place in the new economy. 
This positioning exemplifies the contradictions of market economies. On the one hand, the sector is no longer viewed as backward and low skilled, but is now understood as an essential component of 'creative' advanced capitalist economies and as a sector integral to regional development and place marketing. As the new industry orients to design and fashion, it is forging new associations with consumer goods sectors and creating new market partitions based on lifestyle branding. On the other hand, the Dickensian conditions of the unregulated parts of the Outwork production sector epitomise the dark side of deregulation and the perils of a trade-exposed and market-led economy.

The history of the Australian clothing production industries over the last twenty years demonstrates that no matter how inhospitable the policy settings, the clothing production industries do not disappear from high wage economies. It seems clear from this story that because people want to work in the fashion and clothing industries, neither labour nor capital will ever entirely shift to the more 'efficient' uses predicted by economic theory. However, when these highly mobile industries are exposed to global competition, the price of labour is inevitably pushed downward, creating segments of the Australian workforce - outworkers and young clothing designers working at the edge of unemployment - living at standards well below the national average.

\section{References}

ABS. "Labour Force, Australia," ABS Cat. No. 6291.0.55.003, Detailed Quarterly Estimates, Australian Bureau of Statistics: Ausstats, 2007a.

- - "Consumer Price Index, June 2007," ABS Cat. No. 6401.0. Australian Bureau of Statistics: Ausstats, 2007b.

- - - "Census of Population and Housing, Working Population Profile, Australia," Australian Bureau of Statistics: Ausstats, 2007c.

- - - "Australian National Accounts: Input-Output Tables (Product Details), 2001-02," ABS Cat. No. 5215.0.55.001. Australian Bureau of Statistics: Ausstats, 2007d.

- - - "Manufacturing Industry, Australia, 2004-05," ABS Cat. No. 8221.0. Australian Bureau of Statistics: Ausstats, 2006a.

- - - "Household Expenditure Survey, 2004-05," ABS Cat. No. 6535.0. Australian Bureau of Statistics: Ausstats, 2006b.

- - "Retail Trade, Australia," ABS Cat. No. 8501.01. Australian Bureau of Statistics. Ausstats, 2006c.

ACTU. A Fair Go at Work: Collective Bargaining for Australian Workers, Melbourne: Australian Council of Trade Unions, September 2006.

Anderson, K. and R. Garnaut. Australian Protectionism. Sydney: Allen \& Unwin, 1987.

Bair, J. and G. Gereffi. Inter-firm Networks and Regional Divisions of Labour: Employment and Upgrading in the Apparel Commodity Chain. Geneva: International Institute of Labour Studies, 1998.

Button, J. Revitalising Australia's Textiles, Clothing \& Footwear Industries. Statement by the Minister for Industry, Technology and Commerce, John Button. News Release 166/86. Canberra, 1986.

Commonwealth of Australia. Future Strategies for the Textiles, Clothing and Footwear Industries 1996-2000. Report of the TCF Future Strategies Committee. Canberra: AGPS, 1994.

Gereffi, G. "The Organisation of Buyer-Driven Global Commodity Chains: How US Retailers Shape Overseas Production Networks." Eds. G. Gereffi and M. Korzeniewicz. Commodity Chains and Global Capitalism. Westport Conn.: Greenwood Press, 1994, pp. 95-123. 
Greig, A. W. "Technological Change and Innovation in the Clothing Industry: The Role of Retailing," Labour and Industry, 2.3 (1990): 330-53.

Hawke, R.J., Keating, $\mathrm{P}$ and Button, J. Building a Competitive Australia. Statement by the Prime Minister, Treasurer, and Minister for Industry, Technology and Commerce. Canberra: AGPS, March 1991.

IAC. The Textiles Clothing and Footwear Industries. Volume 1 (Chapters). Industries Assistance Commission Report No. 386. Canberra: Australian Government Publishing Service, 1986.

IC. The Textiles, Clothing and Footwear Industries. Volume 1: Report. Industry Commission Report No.59. Canberra: Australian Government Publishing Service, 1997.

Just Group. Annual Report 2006, Melbourne, 2006. http://www.justgroup.com.au/Communication/JustGroup_AR2006_Web.pdf, last accessed July 2007.

La Frenz, C. "\$A rise boosts key brands," The Herald-Sun/The Herald-Sun, Melbourne, 11 March 2007, p. 17.

Meagher, D. "Designers take a slow coat to China," The Australian, Canberra. 18 May 2007, p.18.

PC. Rules of Origin under the Australia-New Zealand Closer Economic Relations Trade Agreement. Research Report. Canberra: Productivity Commission, 2004.

Porter, M. E. The Competitive Advantage of Nations. London: Macmillan, 1990.

Pusey, M. Economic Rationalism in Canberra. Cambridge: Cambridge University Press, 1991.

Ricardo, R. Principles of Political Economy and Taxation. Cambridge: Cambridge University Press, 1981. (First published, 1817).

Safe, G. "Flying under the Radar," The Australian, 18 July 2007, pp. 17.

Scheffer, M. The Changing Map of European Textiles: Production and Sourcing Strategies of Textile and Clothing Firms. Brussels: OETH (Observatoire Europeen du Textile et de I'Habillement), 1994.

Snape, R. H., L. Gropp and T. Lutrell. Australian Trade Policy 1965-1997. Sydney: Allen \& Unwin, 1998.

TCFUA. The Hidden Cost of Fashion: Report on the National Outwork Information Campaign. Sydney: Textiles Clothing and Footwear Union of Australia, 1995.

TFIA. TFIA Newsletter. Melbourne: Textiles and Fashion Industries of Australia. May 2007.

- - - The Australian TCF Industry - A Profile, mimeo. Melbourne: TFIA Business Services, 2006.

Tungate, M. Fashion Brands: Branding Styles from Armani to Zara. London: Kogan Page, 2005.

Webber, M. and S. Weller. Re-fashioning the Rag Trade: the Internationalisation of the TCF Industries in Australia. Sydney: University of New South Wales Press, 2001.

Weller, S. A. "Fashion as Viscous Knowledge: Fashion's Role in Shaping Trans-National Garment Production," Journal of Economic Geography, 7.1 (2007): 39-66. http://joeg.oxfordjournals.org/cgi/content/abstract/7/1/39

- - - "Networks, Commodity Chains and Crisis: The Impact of Fiji's Coup on Garment Production Networks," Environment \& Planning A, 38.7 (2006): 1249-67.

- - - "International Competitiveness and Export Performance: The Case of Clothing and Textiles," Journal of Australian Political Economy, 46.December (2000): 71-102.

Weller, S. and Webber, M. "Re-employment After Retrenchment: Evidence from the TCF Industry Study," Australian Economic Review, 32.2 (1999): 105-29. 